\title{
PENGARUH MOTIVASI BELAJAR TERHADAP HASIL BELAJAR MATEMATIKA SISWA KELAS VIII SMP NEGERI 1 SAWERIGADI
}

\author{
Gusnawati $^{\text {I) }}$, Anwar Bey, Hasnawati ${ }^{3)}$ \\ ${ }^{1)}$ Alumni Jurusan Pendidikan Matematika, ${ }^{2,3)}$ Dosen Jurusan Pendidikan Matematika \\ FKIP Universitas Halu Oleo Email : watigusna62@gmail.com; \\ Abbey unchb@yahoo.co.id; Hasna fkip@yahoo.co.id
}

\begin{abstract}
Abstrak
Penelitian ini merupakan penelitian expost-facto. Populasi penelitian ini adalah keseluruhan siswa kelas VIII SMP Negeri 1 Sawerigadi yang berjumlah 40 orang yang terdiri dari 20 siswa kelas $\mathrm{VIII}_{\mathrm{A}}$, 20 siswa kelas VIII $_{\mathrm{B}}$. Jumlah sampel dalam penelitian ini adalah 40 siswa. Pengambilan data dilakukan dengan dua cara yaitu tes dan angket. Tes digunakan untuk memperoleh hasil belajar siswa. Angket digunakan untuk memperoleh data yang berkaitan dengan motivasi belajar pada siswa. Teknik analisis data yang digunakan adalah analisis statistik deskriptif dan statistik inferensial. Dari hasil analisis data diperoleh kesimpulan: (1) Analisis deskriptif kelas VIII SMP Negeri 1 Sawerigadi sebanyak 40 siswa pada variabel motivasi belajar diperoleh nilai rata-rata 88,10 (kategori tinggi). Sedangkan variabel hasil belajar matematika nilai rata-rata sebesar 78,20 (kriteria baik). (2) motivasi belajar mempunyai pengaruh yang signifikan terhadap hasil belajar matematika siswa kelas VIII SMP Negeri 1 Sawerigadi, yang ditunjukan dengan $\hat{Y}=39,497+0,439 x$, dengan koefisien determinasi yaitu 0,350 atau $35 \%$.
\end{abstract}

Kata Kunci: motivasi belajar, hasil belajar matematika, ex-post facto

\section{THE EFFECT OF LEARNING MOTIVATION ON THE MATHEMATICS LEARNING OUTCOMES OF CLASS VIII STUDENTS IN 1 SAWERIGADI STATE SMP}

\begin{abstract}
This research is an expost-facto study. The population of this study was all eighth grade students of SMP Negeri 1 Sawerigadi, amounting to 40 people consisting of 20 students of class VIIIA, 20 students of class VIIIB. The number of samples in this study were 40 students. Data retrieval is done in two ways, namely tests and questionnaires. Tests are used to obtain student learning outcomes. Questionnaires are used to obtain data relating to student motivation. The data analysis technique used is descriptive statistical analysis and inferential statistics. From the results of data analysis, conclusions were obtained: (1) Descriptive analysis of class VIII Sawerigadi State Middle School as many as 40 students in the learning motivation variable obtained an average value of 88.10 (high category). While the mathematics learning outcomes variable the average value is 78.20 (good criteria). (2) learning motivation has a significant influence on the mathematics learning outcomes of class VIII students of SMP Negeri 1 Sawerigadi, which is indicated by, with a coefficient of determination of 0.350 or $35 \%$.
\end{abstract}

Keywords: learning motivation, mathematics learning outcomes, ex-post facto 


\section{Pendahuluan}

Pendidikan adalah suatu kegiatan yang dijalankan dengan sengaja, teratur, dan berencana dengan maksud mengubah atau mengembangkan perilaku yang diinginkan. Untuk meningkatkan kualitas dan kuantitas pendidikan banyak upaya yang harus di lakukan oleh pengajar seperti penggunaan tipe pengajaran, pendekatan, strategi dan metode pengajaran, mendorong atau memotivasi siswanya untuk belajar, karena kesemuanya ini merupakan usaha identifikasi komunaksi antara guru dengan siswa dalam proses pembelajaran khususnya pembelajaran matematika.

Matematika merupakan ilmu dasar yang berperan penting dalam upaya penguasaan ilmu pengetahuan dan teknologi sehingga matematika hendaknya dapat dikuasai oleh segenap warga Indonesia meskipun pada batas penguasaan yang berbeda-beda sesuai dengan kebutuhan dan kemampuan masing-masing.

Guru memegang peranan penting dalam proses belajar mengajar, karena guru merupakan orang yang secara langsung memberikan materi pelajaran kepada siswa, sehingga siswa merupakan kunci utama dalam keberhasilan belajar siswa. Dalam proses pembelajaran guru hendaknya mampu mengorganisasikan materi dan kegiatan pembelajaran sedemikian rupa, sehingga tercipta suasana pembelajaran yang inovatif dan menyenangkan. Guru juga harus mampu menerapkan metode mengajar yang tepat yang melibatkan siswa secara aktif dalam proses pembelajaran. Seorang siswa dikatakan dapat mencapai perkembangannya secara optimal apabila siswa dapat memperoleh pendidikan dan hasil belajar yang sesuai dengan bakat, kemampuan dan minat yang dimilikinya.

Siswa merupakan individu yang secara langsung melakukan proses pembelajaran, sehingga siswa harus dapat mengikuti kegiatan pembelajaran dengan aktif. Siswa harus mampu pula mengungkapkan gagasan-gagasan, serta mampu menyertakan segala aspek yang ada pada dirinya baik kecerdasan, minat, perhatian, motivasi, cara belajar dan disiplin belajar, sehingga akan mencapai hasil belajar yang memuaskan.

Hasil belajar adalah suatu hasil dari upaya yang telah dikerjakan yang dapat membuahkan hasil atau nilai yang maksimal. Masalah hasil belajar siswa dan kualitas pendidikan sampai hari ini masih menjadi pokok permasalahan dalam dunia pendidikan di Kabupaten Muna Barat pada khususnya Sulawesi Tenggara pada umumnya. Kualitas hasil belajar yang telah dicapai oleh peserta didik saat ini belum mampu mengangkat kualitas pendidikan. Pentingnya kualitas pendidikan diperhatikan merupakan salah satu bagian pembangunan yang sangat penting dan strategis dalam memajukan Daerah Provinsi Sulawesi Tenggara (La Samutu, 2011: 1).

Slavin (1991) yang mengatakan bahwa motivasi merupakan salah satu prasyarat yang penting dalam belajar. Bila tidak ada motivasi, maka proses pembelajaran tidak akan terjadi, dan motivasi dapat mempengaruhi proses dan hasi belajar.

Menurut Karso (Rasyid, 2015: 10) mengemukakan bahwa matematika merupakan ilmu yang berhubungan dengan penelahan bentuk-bentuk atau struktur yang abstrak diantara hubungan- hubungannya diperlukan penguasaan tentang konsepkonsep yang terdapat dalam matematika. Hal ini berarti matematika merupakan belajar konsep dan struktur yang terdapat dalam bahan yang sedang dipelajari serta mencari hubungan antara konsep dan struktur.

Kecakapan atau kemahiran matematika yang diharpkan dalam pembelajaran matematika mencakup: (a) pemahaman konsep, (b) prosedur, (c) penalaran dan komunikasi, (d) pemecahan masalah, (e) menghargai kegunaan matematika. Demi kepraktisan dan kemudahan, maka aspek penilain matematika dikelompokan menjadi tiga aspek yaitu: (a) pemahaman konsep, (b) penalaran dan komunikasi, dan (c) 
pemecahan masalah. (Jihad dan Haris, 2013: 148-149).

Jihad dan Haris (2013: 14) mengemukakan bahwa Hasila belajar adalah pencapaian bentuk perubahan perilaku yang cenderung menetap dari ranah kognitif, afektif, dan psikomotorik dari proses belajar yang dilakukan dalam waktu tertentu. Untuk memperoleh hasil belajar, dilakukan evaluasi atau penilaian yang merupakan tindak lanjut atau cara untuk mengukur tingkat penguasaan siswa. Nana Sudjana (2009: 3) mendefenisiskan hasil siswa pada hakekatnya adalah perubahan tingkah laku sebagai hasil belajar dalam pengertian yang lebih luas mencangkup bidang kognitif, afektif dan psikomotorik. Slameto (1995: 2) mengemukakan bahwa hasil belajar merupakan suatu proses usaha yang dilakukan seseorang untuk memperoleh suatu perubahan tingkah laku yang baru secara keseluruhan sebagai hasil pengalamannya sendiri. Hamalik (2004: 49) mengemukakan hasil belajar sebagai tingkat penguasaan yang dicapai oleh pelajar dalam mengikuti proses belajar mengajar sesuai dengan tujuan pendidikan yang ditetapkan.

Berdasarkan hasil pengamatan awal dan wawancara dengan guru matematika yang mengajar di kelas VIII SMP Negeri 1 Sawerigadi yang dilakukan pada tanggal 22 Januari 2018, ternyata matematika adalah pelajaran yang tidak disenangi oleh siswa, selain itu motivasi siswa masih tergolong kurang untuk mengikuti kegiatan belajar di kelas, dimana ketika guru menjelaskan mata pelajaran matematika ada siswa yang tidak memperhatikan gurunya karena sibuk bercerita dengan teman sebangkunya, ada juga siswa yang keluar masuk dengan alasan ingin buang air kecil, sehingga siswa masih belum maksimal pencapaiannya atau bisa dikatakan hasil belajarnya masih dibawah rata-rata. Berdasarkan keterangan dari Bapak Bahar selaku guru mata pelajaran matematika bahwa sebagian besar hasil belajar belum mencapai nilai kriteria ketuntasan minimal (KKM) seperti yang di harapkan yaitu 70. Hal ini dapat dilihat dari nilai ulangan semestar siswa kelas VIII yang masih dibawah KKM yaitu sebanyak 27 siswa dari 40 siswa.

Banyak faktor yang mempengaruhi hasil belajar siswa antara lain faktor internal dan faktor eksternal siswa. Faktor internal berkaitan dengan motivasi, minat siswa, intelegensi, sikap, kepercayaan diri siswa dan lain-lain. Sementara yang menjadi faktor eksternal adalah lingkungan sekolah, lingkungan keluarga, lingkungan masyarakat. Kualitas hasil belajar banyak ditentukan oleh faktor guru. Guru menjadi garda terdepan dalam mengadakan perubahan mendasar baik dalam menerapkan kurikulum maupun pengembangannya. Gurulah yang memegang peranan utama dalam pembelajaran dan merupakan inti dari proses pendidikan (Moh. Uzer Usman dalam Maonde, 2009: 2).

Salah satu faktor yang menyebabkan hasil belajar matematika adalah motivasi belajar siswa yang masih kurang baik di dalam maupun di luar sekolah. Hal ini terbukti bahwa pada saat guru mengajar mata pelajaran matematika, ada beberapa siswa yang tidak memperhatikan penjelasan dari guru, ada yang sibuk cerita dengan teman sebangkunya serta keluar masuk kelas dengan alasan izin keluar.

Sebagaimana (Sardiman, 2016: 20) belajar merupakan perubahan tingkah laku atau penampilan dengan serangkaian kegiatan, misalnya dengan membaca, mengamati, mendengarkan, meniru dan lain sebagainya. Belajar juga merupakan suatu proses yang tidak dapat dilihat dengan nyata, proses itu terjadi di dalam diri seseorang yang sedang mengalami belajar. Di dalam belajar juga terdapat proses belajar, proses belajar ini diartikan sebagai perubahan perilaku kognitif, afektif dan psikomotor yang terjadi dalam diri siswa. Belajar banyak dipengaruhi oleh motivasi, baik dari dalam maupun dari luar diri seseorang. Karena motivasi merupakan motor penggerak yang mendorong seseorang untuk melakukan sesuatu termasuk belajar sehingga tujuan belajar tercapai, maka dalam belajar matematika juga diperlukan motivasi yang tinggi agar siswa berpeluang besar 
memperoleh nilai matematika yang tinggi. Tinggi rendahnya motivasi belajar siswa dapat terlihat dari keadaan siswa pada saat mengikuti pembelajaran. Oleh sebab itu tugas pendidikan sekolah yang utama sekarang adalah menanamkan motivasi yang kuat dari anak untuk belajar terus menerus sepanjang hidupnya, memberikan keterampilan pada peserta didik untuk secara cepat dan mengembangkan daya adaptasi yang besar dalam diri peserta didik. Semua itu perlu dikondisikan agar peserta didik termotivasi, karena bagaimanapun juga motivasi merupakan faktor yang sangat menentukan dan berfungsi menimbulkan, mendasari dan mengarahkan perbuatan belajar.

Permasalahan yang sering muncul dalam kegiatan belajar mengajar adalah rendahnya hasil belajar siswa, khususnya pada pelajaran matematika. Kehadiran faktor-faktor psikologis dalam belajar matematika memberikan peran yang cukup penting karena memberikan kemudahan dalam upaya pencapaian tujuan belajar secara optimal, salah satu faktor psikologis adalah motivasi, seseorang akan berhasil dalam belajar apabila pada dirinya ada keinginan untuk belajar. Sehingga menurut Hamzah (2009) motivasi merupakan dorongan dan kekuatan dalam diri seseorang untuk melakukan tujuan tertentu yang ingin dicapainya.

Motivasi adalah suatu kekuatan atau tenaga atau suatu keadaan yang kompleks dan kesiapsediaan dalam diri individu untuk bergerak kearah tujuan tertentu. Mengenai peran penting motivasi dalam proses belajar dikemukakan oleh Slavin (1991) yang mengatakan bahwa motivasi merupakan salah satu prasyarat yang penting dalam belajar. Bila tidak ada motivasi, maka proses pembelajaran tidak akan terjadi, dan motivasi dapat mempengaruhi proses dan hasi belajar.

Salah satu masalah yang dihadapi guru untuk menyelenggarakan pembelajaran adalah bagaimana memotivasi dan menumbuhkan dalam diri siswa secara efektif. Keberhasilan suatu pembelajaran sangat dipengaruhi oleh adanya penyediaan motivasi/dorongan dalam diri siswa untuk mempelajari matematika. Hal ini sering ditemui beberapa kesukaran yang dialami seorang guru dalam memotivasi siswanya adalah tidak adanya pendekatan atau teknik tertentu untuk dapat memotivasi peserta didik dengan cara yang sama atau dengan hasil yang sama. Motivasi dapat dilaksanakan dengan cara pemberian umpan balik terhadap siswa baik secara kelompok maupun secara klasikal. Pemberian umpan balik ini diharapkan agar siswa selalu siap dan senang dalam menerima proses pembelajaran, terutama dalam pembelajaran matematika.

Atas dasar pemikiran tersebut maka penulis tertarik untuk melakukan penelitian yang berjudul "Pengaruh Motivasi Belajar Terhadap Hasil Belajar Matematika Siswa Kelas VIII SMP Negeri 1 Sawerigadi”.

Sardiman (2008: 75) sendiri mengungkapkan bahwa motivasi belajar adalah keseluruhan daya penggerak didalam diri siswa yang menimbulkan kegiatan belajar, yang menjamin kelangsungan kegiatan belajar, sehingga tujuan yang dikehendaki oleh subyek belajar dapat tercapai. Motivasi yang menyebabkan siswa melakukan kegiatan belajar dapat timbul dari dalam dirinya sendiri maupun dari luar dirinya. Sejalan dengan pendapat tersebut, Crhistine (2000: 1) mengungkapkan bahwa motivasi adalah apa yang kita rasakan waktu kita digerakkan untuk mengambil tindakan yang kita inginkan. Oleh Winkel (1996: 151), motivasi adalah daya penggerak didalam diri seseorang untuk melakukan aktivitas-aktivitas tertentu demi mencapai tujuan tertentu.

Berhasil tidaknya seseorang dalam belajar disebabkan beberapa faktor yang mempengaruhi pencapaian hasil belajar. Selanjutnya Slameto (2010: 54) mengemukakan faktor-faktor yang mempengaruhi hasil belajar adalah sebagai berikut.

1. Faktor intern yaitu faktor yang ada dalam diri individu yang sedang belajar. Faktor intern terdiri dari: 
a. Faktor jasmaniah (kesehatan dan catat tubuh).

b. Faktor psikologis (intelegensi, perhatian, minat, bakat, motif, kematangan dan kesiapan).

c. Faktor kelelahan.

2. Faktor ekstern yaitu faktor yang yang ada diluar individu yang sedang belajar. Faktor ekstern terdiri dari:

a. Faktor keluarga (cara orang tua mendidik, relasi antara anggota keluarga, suasana rumah, keadaan ekonomi keluarga, pengertian orang tua, dan latar belakang kebudayaan).

b. Faktor sekolah (metode mengajar, kurikulum, relasi guru dengan siswa, disiplin sekolah, alat pelajaran, waktu sekolah, standar pelajaran di atas ukuran, keadaan gedung, metode belajar, dan tugas rumah).

c. Faktor masyarakat (kegiatan siswa dalam masyarakat, mass media, teman bergaul, dan bentuk kehidupan masyarakat.

Menurut Arikunto (2002: 133) mengatakan "hasil belajar adalah hasil akhir setelah mengalami proses belajar, perubahan itu tampak dalam perbuatan yang dapat diamati dan dapat diukur". Hasil belajar ini merefleksikan keleluasan, kedalaman, dan kompleksitas (secara bergradasi) dan digambarkan secara jelas serta dapat diukur dengan teknik penilaian tertentu. Perbedaan tentang kompetensi dan hasil belajar terdapat pada batasan dan patokan kinerja siswa yang dapat diukur. Menurut Nana Sudjana (2005: 38) hasil belajar yang dicapai oleh siswa di pengaruhi dua faktor utama yakni faktor dalam diri siswa itu dan faktor yang datang dari luar diri siswa atau faktor lingkungan. Faktor yang datang dari siswa terurtama kemampuan yang dimilikinya. Faktor kemampuan siswa besar sekali pengaruhnya terhadap hasil belajar yang dicapai. Disamping faktor kemampuan yang dimiliki siswa, juga ada faktor lain, seperti motivasi belajar, ketekunan, sosial ekonomi, faktor fisik dan psikis. Dymiati dan Mudjiono (2013 :3) berpendapat bahwa hasil belajar merupakan hasil dari suatu interaksi tindak belajar dan tindak mengajar. Dari sisi guru, tindak mengajar diakhiri dengan proses evaluasi hasil belajar. Dari sisi siswa, hasil belajar merupakan berakhirnya penggal dan puncak proses belajar. Soedijarto (1997: 49) mendefenisikan hasil belajar adalah tingkat penguasaan yang dicapai oleh siswa dalam mengikuti program belajar mengajar sesuai dengan tujuan pendidikan yang telah ditetapkan. Hal ini senada dengan Suryabrata (1999: 49) yang mengungkapkan bahwa hasil belajar merupakan salah satu ukuran tingkat keberhasilan siswa setelah menjalani proses belajar. Dimana untuk mengungkapkan pihak guru atau pembimbing biasanya menggunakan alat penilaian atau tes yang betul-betul diharapkan dapat mendeteksi seberapa besar tingkat penguasaan siswa terhadap pelajaran yang telah diberikan.

Dari beberapa uaraian di atas dapat disimpulkan bahwa hasil belajar adalah dasar yang digunakan untuk menentukan tingkat keberhasilan siswa menguasai suatu materi pelajaran. Manusia melakukan kegiatan belajar dengan berbagai macam cara sesuai dengan keadaan. Bila seseorang telah melakukan kegiatan belajar maka dalam dirinya akan terjadi perubahanperubahan yang yang merupakan pernyataan perbuatan belajar, pernyataan ini disebut dengan hasil belajar.

Jadi hasil belajar matematika adalah tolak ukur atau patokan yang menentukan tingkat keberhasilan siswa dalam mengetahui dan memahami suatu materi pelajaran matematika setelah mengalami pengalaman belajar yang dapat diukur melalui tes.

Donald (Sardiman 2008: 90) berpendapat bahwa motivasi adalah perubahan energi dalam diri seseorang yang ditandai dengan munculnya rasa/feeling dan didahului dengan tanggapan terhadap adanya tujuan

Motivasi ekstrinsik adalah hal atau keadaan yang datang dari luar individu siswa, yang mendorongnya untuk melakukan kegiatan belajar. Bentuk motivasi ekstrinsik ini merupakan suatu dorongan yang secara 
mutlak berkaitan dengan aktivitas belajar, misalnya siswa rajin belajar untuk memperoleh hadiah yang telah dijanjikan oleh orang tuanya. Pujian atau hadiah, peraturan atau tata tertib sekolah, suri tauladan orang tua, guru dan lain-lain merupakan contoh konkrit dari motivasi ekstrinsik yang dapat mendorong siswa untuk belajar.

Menurut Sardiman (2008: 92) ada beberapa cara untuk meningatkan motivasi dalam kegiatan belajar di sekolah yaitu: (1)Memberi Nilai Angka dimaksud adalah sebagai simbol atau nilai dari hasil aktivitas belajar anak didik yang diberikan sesuai hasil yang telah mereka peroleh dari hasil penilaian guru yang biasanya terdapat di dalam buku rapor sesuai jumlah mata pelajaran yang diprogramkan dalam kurikulum.(2) Hadiah adalah memberikan sesuatu kepada anak didik yang berprestasi berupa uang beasiswa, buku tulis, alat tulis atau buku bacaan lainnya yang dikumpulkan dalam sebuah kotak terbungkus dengan rapi, untuk memotivasi anak didik agar senantiasa mempertahankan prestasi belajarnya.(3) Kompetisi adalah persaingan yang digunakan sebagai alat memotivasi untuk mendorong anak didik agar mereka bergairah belajar, baik dalam bentuk individu maupun kelompok untuk menjadikan proses belajar mengajar yang kondusif. (4) Pujian yang diucapkan pada waktu yang tepat dapat dijadikan sebagai alat motivasi. Dengan pujian yang diberikan akan membesarkan jiwa anak didik dan akan lebih bergairah belajar bila hasil pekerjaannya dipuji dan diperhatikan, tetapi pujian harus diberikan secara merata kepada anak didik sebagai individu bukan kepada yang cantik atau yang pintar. Dengan begitu anak didik tidak akan antipasti terhadap guru, tetapi merupakan teladan yang disenangi dan dikagumi. (5) Hukuman Meskipun hukuman sebagai reinforcement yang negatif, tetapi bila dilakukan dengan tepat dan bijak akan merupakan alat motivasi yang baik dan efektif. Hukuman mendidik bertujuan memperbaiki sikap dan perbuatan anak didik yang dianggap salah dapat berupa sanksi yang diberikan kepada anak didik sesuai dengan kesalahan atau pelanggaran di hari mendatang.

\section{Metode}

penelitian yang digunakan adalah $e x$ post facto. Musfiqun (2012: 68) mengemukakan bahwa penelitian dengan pendekatan ex post facto adalah penelitian yang mencari hubungan sebab akibat yang tidak dimanipulasi atau diberi perlakuan oleh peneliti. Berbeda dengan penelitian eksperimen, yang variabelnya didesain dan dimanipulasi oleh peneliti.

populasi adalah keseluruhan objek penelitian (2008: 115). Populasi dalam penelitian ini adalah keseluruhan siswa kelas VIII SMP Negeri 1 Sawerigadi yang berjumlah 40 siswa yang terdiri dari 20 siswa kelas $V I I I_{A}$ dan 20 siswa kelas $V I I I_{B}$. Jadi sampel dalam penelitian ini adalah seluruh siswa kelas VIII SMP Negeri 1 Sawerigadi yang berjumlah 40 orang.

Variabel dalam penelitian ini terdiri dari satu variabel bebas yakni motivasi belajar (X), dan satu variabel terikat yakni hasil belajar matematika (Y). Untuk melihat gambaran hubungan antara kedua variabel dalam penelitian ini, dapat dilihat dalam desain penelitian berikut:

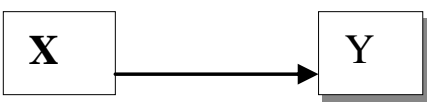

Gambar 1. Desain Penelitian

$\begin{array}{ll}\text { Keterangan: } & \mathrm{X}=\text { Motivasi Belajar } \\ & \mathrm{Y}=\text { Hasil Belajar }\end{array}$

Matematika

Instrumen yang digunakan dalam penelitian ini adalah perangkat tes yang terdiri dari tes motivasi belajar siswa berbentuk angket dan tes hasil belajar matematika berbentuk soal pilihan ganda. Tes motivasi belajar siswa terdiri dari 23 butir pernyataan, dimana pada penelitian ini peneliti melakukan uji coba pada instrument angket motivasi belajar dan tes hasil belajar matematika terdiri dari 20 butir soal yang dipanelis valid semua kemudian di uji cobakan yang valid tinggal 12 butir soal. 
Validitas tes hasil belajar matematika dihitung dengan menggunakan rumus aiken, yaitu:

$$
V_{i}=\frac{\sum n_{i}\left|i-i_{0}\right|}{N(c-1)}
$$

(Patih, 2012: 36)

Aiken

Keterangan :

$$
\begin{array}{ll}
V_{i} & : \text { validitas isi } \\
n_{i} & : \text { jumlah panelis yang }
\end{array}
$$

memilih i

$i$ : skor pilihan setiap butir instrumen

$i_{0} \quad$ : skor paling rendah

yaitu 1

$N \quad$ : jumlah penelis

$c$ : skor pilihan yang

tertinggi yaitu 5

Validitas tiap butir kuesioner disiplin belajar siswa ditentukan oleh nilai $V_{i}$ dengan kriteria pengujian, jika $V_{i}>0,60$ maka butir tersebut valid dan jika $V_{i} \leq 0,60$ maka butir tersebut tidak valid.

Hasil analisis validitas instrumen berdasarkan uji coba angket yang dilakukan di SMP Negeri 1 Barangka. Uji coba dilakukan kepada 20 orang siswa kelas VIII $_{1}$. Validitas angket motivasi belajar dihitung dengan metode pearson product moment dengan mengkorelasikan antara skor yang didapat siswa pada butir angket dengan skor total yang didapat. Rumus yang digunakan yaitu sebagai berikut.

$$
\begin{aligned}
& r_{X Y}= \\
& \frac{N \sum X Y-\left(\sum X\right)\left(\sum Y\right)}{\sqrt{\left\{N \sum X^{2}-\left(\sum X\right)^{2}\right\}\left\{N \sum Y^{2}-\left(\sum Y\right)^{2}\right\}}} \\
& \text { (Lestari\&Yudhanegara, 2015: } \\
& \text { 193) }
\end{aligned}
$$

Keterangan:

$\mathrm{r}_{\mathrm{xy}} \quad=$ Koefisien korelasi antara variabel $\mathrm{X}$ dan Variabel $\mathrm{Y}$

$\mathrm{N} \quad$ = banyak subjek

$\mathrm{X}=$ Skor item

$\mathrm{Y}=$ Skor total

Semakin tinggi $r_{x y}$ suatu butir instrumen semakin tinggi konstribusi butir itu dalam mengukur sasaran ukurnya (variabel yang diukur). Selanjutnya hasil- hasil perhitungan dibandingkan dengan nilai r-kritis (r-tabel) pada taraf signifikansi $\alpha=$ 0,05 . Kriteria pengujiannya adalah jika $r_{\text {hitung }}>r_{\text {tabel }}$ berarti butir tersebut valid. Sebaliknya jika $r_{\text {hitung }} \leq r_{\text {tabel }}$ maka butir tersebut tidak valid (Ahiri dan Hafid, 2011: 251). Setelah dilakukan validasi dengan uji coba instrument motivasi belajar pada siswa kelas VIII 1 SMP Negeri 1 Barangka, maka butir angket yang valid adalah 23 butir angket.

Berdasarkan hasil analisis uji validitas berdasarkan uji coba angket motivasi belajar pada lampiran 11, tampak bahwa dari 33 butir angket yang diberikan, terdapat 23 butir angket yang dinyatakan valid dan 10 butir angket yang tidak valid. Sedangkan analisis uji validitasnya hasil belajar matematika pada lampiran 13 diketahui bahwa hasil dari 20 butir soal yang diberikan terdapat 12 butir soal yang dinyatakan valid dan 8 butir soal yang tidak valid.

Rumus yang digunakan untuk mengetahui reliabilitas hasil belajar matematika berdasarkan penilaian panelis dan angket motivasi belajar berdasarkan uji coba adalah dengan menggunakan rumus Alpha Cronbach, yaitu sebagai berikut.

$$
r_{i t}=\left(\frac{n}{n-1}\right)\left(1-\frac{\sum s_{i}^{2}}{s_{t}^{2}}\right)
$$

(Jihad, Asep \& Abdul Haris, 2012:180)

Dengan:

$$
\begin{aligned}
& \mathrm{n} \text { = Banyaknya item } \\
& s_{i}{ }^{2}=\quad \text { Jumlah } \\
& s_{t}{ }^{2}=\quad \text { Varians }
\end{aligned}
$$

varians skor tiap item

skor total

Rumus mencari varians adalah:

$$
s^{2}=\frac{\sum x^{2}-\frac{\left(\sum x\right)^{2}}{n}}{n}
$$

Interpretasi nilai $r_{i t}$ mengacu pada pendapat Guilford dalam Jihad dan Haris (2012) yang dapat dilihat pada tabel berikut. 
Tabel 1.

Intepretasi Reliabilitas

\begin{tabular}{|c|c|}
\hline Besarnya nilai $r$ & Interpretasi \\
\hline$r_{i t} \leq 0,20$ & Sangat rendah \\
$0,20<r_{i t} \leq 0,40$ & Rendah \\
$0,40<r_{i t} \leq 0,70$ & Sedang \\
$0,70<r_{i t} \leq 0,90$ & Tinggi \\
$0,90<r_{i t} \leq 1,00$ & Sangat tinggi \\
\hline
\end{tabular}

(Jihad \& Haris, 2012: 180)

Berdasarkan tabel interpretasi reliabilitas, dapat disimpulkan bahwa reliabilitas instrumen reliabel jika $r_{i t}>0,40$ dan tidak reliabel jika $r_{i t}<0,40$.

Berdasarkan hasil analisis reliabilitas pada lampiran 11, dapat diambil kesimpulan bahwa instrumen motivasi belajar reliabel dengan interpretasi reliabilitasnya berada pada $0,70 \leq \mathrm{r}<0,90$ sehingga reliabilitasnya dikatakan tinggi. Artinya instrumen tersebut dapat dipakai sebagai alat ukur untuk dapat mengukur tingkat motivasi belajar siswa. Sedangkan untuk hasil analisis reliabilitas pada instrumen hasil belajar matematika berdasarkan uji panelis yaitu terdapat pada lampiran 12 dan diperoleh koefisien reliabilitas $\left(r_{i t}\right)$ sebesar 0,716 sesuai dengan kriteria interpretasi reliabilitas yakni, 0,70 < $\mathrm{r}_{\mathrm{it}} \leq 0,90$ sehingga reliabilitasnya berada pada kategori tinggi. Dan hasil analisis reliabilitas berdasarkan uji coba pada lampiran 13, diperoleh nilai koefisien reliabiltas dengan menggunakan Microsoft Excel dan Aplikasi SPSS adalah sebesar $\left(r_{i t}\right)$ 0,514 sesuai dengan kriteria interpretasi reliabilitas yakni, $0,40<\mathrm{r}_{\text {it }} \leq 0,70$ sehingga reliabilitasnya berada pada kategori sedang. Jadi soal-soal tersebut dinyatakan reliabel. Artinya instrumen tersebut dapat dipakai sebagai alat ukur untuk dapat mengukur hasil belajar matematika siswa.

Teknik yang digunakan untuk mengumpulkan data dalam penelitian ini adalah pemberian angket dan pemberian tes. Angket diberikan untuk mengukur tingkat motivasi belajar siswa dan tes digunakan untuk mengukur hasil belajar matematika siswa. Sebelum peneliti masuk memberikan angket ataupun tes dikelas, guru matematika yang mengajar dikelas tersebut terlebih

dahulu menginformasikan pada setiap kelas untuk persiapan mengisi angket dan mempelajari materi yang memuat tes hasil belajar, Adapun materi tersebut adalah materi tentang pola bilangan dan statistik yang berbentuk soal pilihan ganda.

Analisis data dalam penelitian ini menggunakan analisis deskriptif dan analisis inferensial. Analisis deskriptif digunakan untuk mendeskriptifkan karakteristik data masing-masing kelompok dan analisis inferensial digunakan untuk menguji hipotesis dengan menggunakan statistik regresi linear sederhana. Analisis deskriptif digunakan untuk mendeskripsikan data penelitian yang diperoleh berupa perolehan skor rata-rata, median, modus, standar deviasi, varians, nilai maksimum dan nilai minimum. Analisis deskriptif ini dilakukan pada kedua variabel penelitian, yaitu motivasi belajar dan hasil belajar matematika. Sedangkan Analisis inferensial digunakan untuk pengujian hipotesis penelitian. Namun, sebelum dilakukan uji hipotesis terlebih dahulu dilakukan uji prasyarat yaitu uji normalitas dan uji linearitas. Uji normalitas data digunakan untuk mengetahui apakah data yang diperoleh dalam penelitian ini berasal dari populasi berdistribusi normal atau tidak. Pengujian normalitas data menggunakan uji Kolmogrov-Smirnov dengan bantuan program SPSS. Sedangkan Uji linearitas digunakan untuk mengetahui apakah motivasi belajar siswa dan hasil belajar matematika mempunyai hubungan garis linear. Uji linearitas pada penelitian ini menggunakan program SPSS. 
Hasil

Ukuran statistik data diperoleh dari analisis data motivasi belajar siswa dan tes hasil belajar matematika yang dilaksanakan terhadap sampel yang berjumlah 40 orang,

Tabel 2.

Analisis Deskriptif Motivasi Belajar dan Hasil Belajar Matematika Siswa Kelas VIII SMP Negeri 1 Sawerigadi

Statistics

\begin{tabular}{|l|l|l|l|}
\hline & & $\mathrm{X}$ & $\mathrm{Y}$ \\
\hline \multirow{2}{*}{$\mathrm{N}$} & Valid & 40 & 40 \\
\cline { 2 - 4 } \multicolumn{2}{|l|}{ Missing } & 0 & 0 \\
\hline \multicolumn{2}{|l|}{ Mean } & 88.10 & 78.20 \\
\hline Median & 89.50 & 75.00 \\
\hline Mode & 73 & 83 \\
\hline Std. Deviation & 12.764 & 9.482 \\
\hline Variance & 162.913 & 89.908 \\
\hline Minimum & 51 & 66 \\
\hline Maximum & 107 & 100 \\
\hline
\end{tabular}

a. Multiple modes exist. The smallest value is shown

Berdasarkan Tabel 2, variabel motivasi belajar dapat dijelaskan dari sampel yang diambil sebanyak 40 siswa bahwa skor ratarata (mean) yang diperoleh sebesar 88,10 dengan median 89,50 . Nilai modus sebesar 73, sedangkan skor tertinggi (nilai maksimum) diperoleh sebesar 107, skor terendah (nilai minimum) sebesar 51dengan standar deviasi 12,764. Pada variabel hasil belajar matematika dari 40 siswa diperoleh nilai rata-rata (mean) sebesar 78,20 dengan median 75. Nilai modus sebesar 83 sedangkan skor tertinggi (nilai maksimum) diperoleh sebesar 100 skor terendah (nilai minimum) sebesar 66 dengan standar deviasi 9,482 . Nilai rata-rata yang diperoleh pada kedua variabel tersebut menunjukkan bahwa mendekati nilai rata-rata.
Berdasarkan hasil analisis deskriptif dengan olahan SPSS diperoleh data motivasi belajar dan hasil belajar matematika kelas VIII yang disajikan pada Tabel 2 berikut:

nilai 88,10 mewakili keseluruhan distribusi motivasi belajar siswa pada kelas VIII dan nilai 78,20 mewakili keseluruhan distribusi nilai hasil belajar matematika siswa kelas VIII. Rendahnya standar deviasi yang diperoleh menunjukkan bahwa data tiap individu berkisar dinilai rata-rata. Dimana semakin kecil nilai standar deviasi yang diperoleh maka semakin kecil pula jarak tiap individu terhadap rata-rata. Nilai standar deviasi yang diperoleh lebih kecil dibandingkan nilai rata-rata sehingga nilai rata-rata yang diperoleh dapat digunakan sebagai representasi dari keseluruhan data. Hal ini karena nilai setiap individu 
Tabel 3.

Hasil Analisis Statistik Uji Normalitas Data untuk Variabel X dan Variabel Y

One-Sample Kolmogorov-Smirnov Test

\begin{tabular}{|c|c|c|c|}
\hline & & $\mathrm{X}$ & $Y$ \\
\hline \multicolumn{2}{|l|}{$\mathrm{N}$} & 40 & 40 \\
\hline \multirow[t]{2}{*}{ Normal Parameters $^{\mathrm{a}}$} & Mean & 88.10 & 78.20 \\
\hline & Std. Deviation & 12.764 & 9.482 \\
\hline \multirow{3}{*}{$\begin{array}{l}\text { Most Extreme } \\
\text { Differences }\end{array}$} & Absolute & .091 & .169 \\
\hline & Positive & .069 & .157 \\
\hline & Negative & -.091 & -.169 \\
\hline \multicolumn{2}{|l|}{ Kolmogorov-Smirnov Z } & .573 & 1.067 \\
\hline \multicolumn{2}{|l|}{ Asymp. Sig. (2-tailed) } & .897 & .205 \\
\hline
\end{tabular}

a. Test distribution is Normal.

Berdasarkan tabel 3. dapat dilihat bahwa uji normalitas dengan menggunakan uji Kolmogrov-Smirnov untuk variabel motivasi belajar (X) diperoleh nilai signifikansi sebesar 0,897.Nilai signifikansi tersebut lebih besar dari nilai $\alpha(0,897>0,05)$. Dengan demikian dapat disimpulkan bahwa $\mathrm{H}_{0}$ diterima atau dengan kata lain pada taraf kepercayaan 95\%, data motivasi belajar berdistribusi normal. Selanjutnya, uji normalitas dengan menggunakan uji Kolmogrov-Smirnov untuk variabel hasi belajar matematika (Y) diperoleh nilai signifikansi sebesar 0,205. Nilai signifikansi tersebut lebih besar dari nilai $\alpha(0,205>$ 0,05). Dengan demikian dapat disimpulkan bahwa $\mathrm{H}_{0}$ diterima atau dengan kata lain pada taraf kepercayaan $95 \%$, data hasil belajar matematika berdistribusi normal.

Tabel 4.

Hasil Analisis Statistik Uji Regresi

Coefficients $^{\mathrm{a}}$

\begin{tabular}{|c|c|c|c|c|c|c|}
\hline \multirow{2}{*}{\multicolumn{2}{|c|}{ Model }} & \multicolumn{2}{|c|}{$\begin{array}{c}\text { Unstandardized } \\
\text { Coefficients }\end{array}$} & \multirow{2}{*}{\begin{tabular}{|c|}
$\begin{array}{c}\text { Standardize } \\
\mathrm{d} \\
\text { Coefficient } \\
\mathrm{s}\end{array}$ \\
Beta
\end{tabular}} & \multirow[t]{2}{*}{$\mathrm{t}$} & \multirow[t]{2}{*}{ Sig. } \\
\hline & & B & Std. Error & & & \\
\hline & (Constant) & 39,497 & 8,649 & & 4,567 & ,000 \\
\hline & $\mathrm{X}$ & ,439 & ,097 & ,591 & 4,521 & ,000 \\
\hline
\end{tabular}

a. Dependent Variable: y

Hasil analisis uji regresi Tabel 4, diperoleh nilai konstan sebesar 39,497 dan nilai koefisien motivasi belaajar sebesar 0,439. Hal ini dapat dibuat persamaan fungsi taksiran regresinya adalah $\hat{Y}=39,497+$ $0,439 X$. ini berarti bahwa kenaikan variabel motivsi belajar meningkat satu satuan, maka nilai hasil belajar akan meningkat sebesar 0,439 satuan dengan nilai konstanta 39,497. Selain itu diperoleh nilai signifikan sebesar 0,000 dengan $\alpha=0,05$ karena $0,000<0,05$ maka $\mathrm{H}_{0}$ ditolak. Dengan demikian dapat 
disimpulkan bahwa motivasi belajar terhadap hasil belajar matematika siswa mempunyai pengaruh yang signifikan kelas VIII SMP Negeri 1 Sawerigadi.

Tabel 5

Koefisien Determinasi

Model Summary

\begin{tabular}{|l|r|r|r|r|}
\hline Model & \multicolumn{1}{|c|}{$\mathrm{R}$} & R Square & $\begin{array}{c}\text { Adjusted R } \\
\text { Square }\end{array}$ & $\begin{array}{r}\text { Std. Error of } \\
\text { the Estimate }\end{array}$ \\
\hline 1 &, $591^{\mathrm{a}}$ &, 350 &, 333 & 7,746 \\
\hline
\end{tabular}

a. Predictors: (Constant), $\mathrm{x}$

Dari tabel 5. diperoleh bahwa besarnya pengaruh variabel motivasi belajar terhadap hasil belajar matematika siswa kelas VIII SMP Negeri 1 Sawerigadi dapat diketahui melalui besarnya koefisien determinasi $\left(\mathrm{R}^{2}\right)$ yang dinyatakan dalam persentase.

Hasilnya sebagai berikut:

$\mathrm{R}^{2}=(0,591)^{2} \times 100 \%$

$=0,350 \times 100$

$=35 \%$

Dari hasil perhitungan diatas maka dapat disimpulkan bahwa besarnya kontribusi variable motivasi belajar terhadap hasil belajar matematika siswa adalah $35 \%$ dan selebihnya yang $65 \%$ dipengaruhi oleh faktor lain.

\section{Pembahasan}

Motivasi belajar adalah keseluruhan daya penggerak di dalam diri siswa yang menimbulkan kegiatan belajar, yang menjamin kelangsungan dari kegiatan belajar dan memberikan arah pada kegiatan belajar sehingga tujuan yang dikehendaki oleh subyek belajar itu dapat tercapai..

Hasil belajar matematika adalah tolak ukur atau patokan yang menentukan tingkat keberhasilan siswa dalam mengetahui dan memahami suatu materi pelajaran matematika setelah mengalami pengalaman belajar yang dapat diukur melalui tes. Konsep-konsep matematika tersusun secara hierarkis, konsep yang satu menjadi dasar untuk mempelajari konsep selanjutnya. Sifat ini menyebabkan penguasaan matematika siswa pada proses pembelajaran dipengaruhi oleh motivasinya menguasai konsep matematika sebelumnya. Hal ini mengakibatkan motivasi belajar siswa sangat bergantung pada penguasaan konsep dasar matematika yang telah mereka peroleh dijenjang Sekolah dasar.

Penelitian ini diambil sampel sebanyak 40 siswa kelas VIII SMP Negeri 1 Sawerigadi. Berdasarkan hasil analisis deskriptif kelas VIII dari 40 siswa diperoleh skor rata-rata (mean) motivasi belajar sebesar 88,10 ini berarti berdasarkan table frekuensi motivasi belajar siswa kelas VIII berada pada kategori tinggi. Dengan standar deviasi 12,764 . Nilai median 89,50 artinya setengah dari keseluruhan siswa kelas VIII nilai motivasi belajar diatas 89,50 dan setengah lagi dibawah 89,50. Nilai modus sebesar 73, artinya jumlah motivasi belajar yang paling banyak nilainya sebesar 73.Sedangkan skor tertinggi (nilai maksimum) diperoleh sebesar 107, artinya dari semua data yang diperoleh siswa nilai tertinggi adalah 107. Untuk nilai minimum sebesar 51, artinya dari semua data yang diperoleh siswa dengan skor terendahnya adalah 51.

Pada variabel hasil belajar matematika dari 40 siswa diperoleh nilai rata-rata (mean) sebesar 78,20 ini berarti dari hasil belajar matematika siswa kelas VIII termasuk pada kriteria cukup. Dengan standar deviasi 9,482. Nilai median 75 , nilai 
modus sebesar 83 , artinya jumlah nilai hasil belajar siswa yang paling banyak nilainya sebesar 83. Sedangkan nilai tertinggi (nilai maksimum) diperoleh sebesar 100 dan nilai minimum sebersar 66.

Berdasarkan tabel 4.2 dapat dilihat bahwa motivasi belajar keseluruhan siswa kelas VIII SMP Negeri 1 Sawerigadi terdiri atas 10 siswa $(25 \%)$ motovasi belajar berkategori sangat tinggi, 21 siswa $(52,5 \%)$ motovasi belajarberkategori tinggi, dan 9 siswa $(22,5 \%)$ motovasi belajar berkategori sedang. Berdasarkan hal ini dapat dikatakan bahwa secara keseluruhan dari perolehan nilai siswa untuk tes motovasi belajar yang dilakukan tergolong kategori tinggi karena memiliki persentase terbesar dibanding dengan kategori-kategori lainnya.

Distribusi frekuensi hasil belajar matematika siswa kelas VIII semester ganjil SMP Negeri 1 Sawerigadi menunjukan bahwa dari 40 siswa kelas VIII, siswa yang hasil belajarnya sangat baik sebanyak 6 siswa (15\%), siswa yang hasil belajarnya baik sebanyak 13 siswa $(32,5 \%)$, siswa yang hasil belajarnya cukup sebanyak 11 siswa $(27,5 \%)$ dan yang hasil belajarnya kurang sebanyak 10 siswa $(25 \%)$. Berdasarkan hal ini dapat dikatakan bahwa secara keseluruhan dari perolehan nilai siswa untuk tes hasil belajar matematika yang dilakukan tergolong kategori baik karena memiliki persentase terbesar dibanding dengan kategori-kategori lainnya.

Pengaruh motivasi belajar terhadap hasil belajar matematika siswa kelas VIII SMP Negeri 1 Sawerigadi diperoleh dengan melakukan uji hipotesis menggunakan analisis regresi linear sederhana. Namun, sebelum dilakukan uji hipotesis, terlebih dahulu dilakukan uji normalitas data dan uji linearitas data. Hasil uji normalitas data menggunakan uji kolmogorov-smirnov, data motivasi belajar dan hasil belajar matematika pada keseluruhan siswa kelas VIII SMP Negeri 1 Sawerigadi untuk sampel berdistribusi normal. Hasil uji linearitas antara motivasi belajar dan hasil belajar matematika siswa kelas VIII SMP Negeri 1
Sawerigadi untuk sampel memiliki hubungan yang linear.

Hasil analisis uji regresi tabel 4.6 diperoleh nilai konstan sebesar $\quad 39,497$ dan nilai koefisien motivasi belajar sebesar 0,439 . Hal ini dapat dibuat fungsi taksiran regresinya adalah $\hat{Y}=39,497+0,439 x$. Ini berarti bahwa kenaikan variabel motivasi belajar meningkat 1 satuan, maka nilai hasil belajar akan meningkat sebesar 0,439 satuan dengan nilai konstanta 39,497. Selain itu diperoleh nilai signifikan sebesar 0,000 dengan $\alpha=0,05$ karena $0,000<0,05$ maka $\mathrm{H}_{0}$ ditolak. Dengan demikian dapat disimpulkan bahwa motivasi belajar siswa mempunyai pengaruh yang signifikan terhadap hasil belajar matematika siswa kelas VIII SMP Negeri 1 Sawerigadi.

Nilai koefisien determinasi $\left(\mathrm{R}^{2}\right)$ sebesar sebesar $35, \%$, ini berarti bahwa $35 \%$ sumbangan yang terjadi pada hasil belajar matematika siswa dipengaruhi oleh motivasi belajar siswa, selebihnya $65 \%$ dipengaruhi oleh faktor lainnya yang tidak diteliti dalam penelitian ini. Selain itu, diperoleh nilai signifikan sebesar 0,000 dengan $\alpha=0,05$. Karena $p=0,000<\alpha=0,05$ maka $\mathrm{H}_{0}$ ditolak. Dengan ditolaknya $\mathrm{H}_{0}$ maka dapat disimpulkan bahwa motivasi belajar mempunyai pengaruh yang signifikan terhadap hasil belajar matematika siswa kelas VIII SMP Negeri 1 Sawerigadi.

Penelitian ini berhasil menemukan bahwa motivasi belajar berpengaruh positif terhadap hasil belajar matematika siswa. Bentuk pengaruh motivasi belajar dengan hasil belajar matematika adalah pengaruh positif yang ditunjukkan dengan nilai-nilai regresi yang bertanda positif. Hal ini dapat dilihat pada persamaan regresi $\hat{Y}=39,497+$ 0,439x. Dari fungsi tafsiran regresi tersebut terlihat bahwa nilai konstanta 39,497 merupakan nilai hasil belajar matematika siswa tanpa ditunjang oleh motivasi belajar. Sedangkan koefisien arah regresi $x$ sebesar 0,439 menunjukkan motivasi belajar berpengaruh positif terhadap hasil belajar matematika. Dengan demikian, dapat dijelaskan bahwa jika variabel motivasi 
belajar meningkat, maka akan diikuti dengan meningkatnya hasil belajar matematika siswa. Demikian sebaliknya, jika variabel motivasi belajar menurun, maka akan diikuti dengan menurunnya hasil belajar matematika siswa.

Pengujian berdasarkan analisis statistik uji regresi linear sederhana menunjukkan bahwa motivasi belajar mempunyai konstribusi positif yang signifikan terhadap hasil belajar matematika. Dengan signifikannya pengaruh motivasi belajar tersebut, secara teoritis siswa yang memiliki motivasi yang baik akan memperoleh hasil belajar matematika yang meningkat. Hal ini sesuai dengan teori yang dikemukakan oleh Arbain bahwa motivasi belajar dapat memberikan konstribusi dalam upaya mencapai tujuan belajar matematika secara optimal. Artinya siswa yang memiliki motivasi belajar yang baik menjadi indikator utama untuk mengukur hasil belajar matematika.

\section{Simpulan dan Saran}

\section{Simpulan}

Berdasarkan hasil penelitian dan pembahasan, maka diperoleh beberapa kesimpulan sebagai berikut.

1. Analisis deskriptif kelas VIII SMP Negeri 1 Sawerigadi sebanyak 40 siswa pada variabel motivasi belajar diperoleh nilai rata-rata 88,10 (kategori tinggi). Nilai maksimum 107 dan nilai minimum 51 dengan standar deviasi 12,764. Sedangkan variabel hasil belajar matematika nilai rata-rata sebesar 78,20 (kriteria baik). Nilai maksimum 100 dan nilai minimum 66 dengan standar deviasi 9,482

2. Motivasi belajar mempunyai pengaruh yang signifikan terhadap hasil belajar matematika siswa kelas VIII SMP Negeri 1 Sawerigadi, yang ditunjukan dengan $\hat{Y}=39,497+0,439 x$, dengan koefisien determinasi yaitu 0,350 atau $35 \%$.

\section{Saran}

Berdasarkan hasil penelitian, maka peneliti menyarankan:

1. Motivasi belajar siswa kelas VIII SMP Negeri 1 Sawerigadi tahun pelajaran 2018/2019 semester ganjil masih kurang, oleh karena itu perlu ditingkatkan lagi agar hasil belajar yang diperoleh juga meningkat.

2. Hasil belajar matematika siswa kelas VIII SMP Negeri 1 Sawerigadi masih kurang, maka guru harus selalu memberi motivasi atau mendorong siswa sebelum proses belajar mengajar untuk mengikuti proses pembelajaran dengan serius sehingga siswa mau belajar matematika dan mendapatkan hasil belajar matematika yang memuaskan. Siswa yang mempunyai motivasi belajar yang baik, maka siswa tersebut akan mempunyai hasil belajar matematika yang baik pula.

\section{Daftar Pustaka}

Abdul Haris, Asep Jihad.( 2013). Evaluasi P embelajaran, Yogyakarta: Multi

Pressindo.

Abdul Halim. (2009). Akuntansi sector Publik Keuangan Daerah, Edisi Pertama. Jakarta: Salemba Empat.

Hudoyo, H. (1988). Strategi Belajar Mengajar Matematika. Jakarta: DepDikbud.

Hamzah B. Uno. (2009). Teori Motivasi dan pengukurannya (Analisis di Bidang Pendidikan). Jakarta: PT Bumi Aksara.

Jihad Asep \& Abdul Haris. (2012). Evaluasi Pembelajaran. Yogyakarta : Multi Persindo.

La Samutu. (2011). Pengaruh Model Pembelajaran Kooperatif dan Umpan Balik Penilaian Terhadap Hasil Belajar Matematika (Studi Eksperimen Pada Siswa Kelas VIII SMP Negeri 1 Lawa) Kabupaten Muna. Kendari: Universitas Halu Oleo. 
Suherman, dkk.(2003). Strategi Belajar Mengajar Metematika. Jakarta: Universitas Terbuka.

Sardiman. (2007). Interaksi dan Motivasi Belajar Mengajar. Jakarta: Jakarta: Raja Grafindo Persada.

Sardiman, A.M. (2016). Interaksi dan Motivasi Belajar Mengajar. Jakarta: Rajawali Pers
Sardiman.(2000). Interaksi Dan Motivasi Be lajar Mengajar. Jakarta: Raja Grafindo Persada.

Sudjana.(2001).Penilaian Hsil Belajar Mengajar. PT Remaja Rosda karya: Bandung.

Sugiyono. (2009). Metode Penelitian Kuantitatif, Kualitatifdan $R \& D$. Bandung: Alfabeta. 